MIOMIR KORAĆ

Institute of Archaeology,

Belgrade, Serbia

misko@ai.sanu.ac.rs

ŽIVKO MIKIĆ

Belgrade University, Faculty of Philosophy,

Department of Archaeology

Belgrade, Serbia
$902.2: 572.7(497.11)$

904:726.8"652"(497.11)

COBISS.SR-ID 219296268

Original research article

Received: April 25th 2015

Accepted: November 15th 2015

\title{
VIMINACIUM - CEMETERIES AND BURIAL LOCATIONS DURING THE GREAT MIGRATION PERIOD
}

\begin{abstract}
Although there have been several papers published on the inhabitants of Viminacium during the Great Migration, in this paper, the number of their cemeteries will be considered. According to the archaeological categorisation, four cemeteries have been distinguished: Viminacium I, the BURDELJ necropolis, Viminacium II, the older and the younger cemetery at the VIŠE GROBALJA site, and finally Viminacium III - the necropolis excavated at the LANCI site.

According to anthropological finds, consisting of two artificially deformed skulls, during the Great Migration, the inhabitants of Viminacium were buried at the "mixed" necropolis of PEĆINE, as well as at the site of NJIVE KOD MLAVE.
\end{abstract}

KEYWORDS: THE GREAT MIGRATION, INHABITANTS, VIMINACIUM CEMETERIES, NECROPOLIS SITE, ANTHROPOLOGICAL CONTENT OF NECROPOLIS.

\section{INTRODUCTION ${ }^{1}$}

In previous publications (Mikić 2007), the anthropological features of the Viminacium inhabitants during the Great Migration were considered. The data was obtained from the anthropological content of three cemeteries at the sites of Burdelj and Više Grobalja (the older and the younger necropolis). A fourth necropolis from the same period, at the site of Lanci (Ivanišević et al. 2006),

1 The article results from the project: IRS - Viminacium, Roman city and military legion camp - research of the material and non material culture of inhabitants by using the modern technologies of remote detection, geophysics, GIS, digitalisation and $3 D$ visualisation (no 47018), funded by the Ministry of Education, Science and Technological Development of the Republic of Serbia. was also excavated, but suitable conditions did not exist for the examination of the skeletons and the data has now been lost.

During the Great Migration, in Viminacium, burials also took place at a fifth location - Njive kod Mlave. During excavation, a female skeleton was discovered, with a skull displaying a typical artificial (parietal) deformity, caused by carrying weight secured with a band over the head. As a grave-good, there was a typical Germanic fibula, which, according to archaeological-chronological criteria, belonged to the period of Great Migration. All these elements were recently published (Mikić 2014). Since only a single, so-called top-sondage, was excavated, the question remains regarding the size of the necropolis. 
This paper concerns an artificially deformed skull, discovered at the Pećine site, in sondage number 159. Its specific morphology was documented using an X-ray image, positively indicating that there was also a sixth location, a necropolis, at which the Viminacium inhabitants were buried during the Great Migration.

\section{MATERIAL AND METHOD}

Even as an isolated find, an artificially deformed skull represents conclusive proof that during the Great Migration, in Viminacium, within the Roman cemetery of Pećine, burials took place. The skull is from grave number 1542, discovered within an extension of sondage 159 (M. Korać conducted the excavation of the entire sondage). Field diary pages 1,533 and 1,534 reveal the following data: "G-1542 is positioned in the eastern extension of the profile $3-4$, at a depth of 0.48. The skull of the deceased was in the profile, therefore requiring an extension. The extension begins at $3.70 \mathrm{~m}$ from T.3 towards the south. The extension measures $3.30 \times 1.40 \mathrm{~m}$. The skeleton is orientated west-east, with a deviation of $27^{\circ}$ of its western part towards the south. It was a simple grave pit, while the deceased was placed on its back, in an outstretched position. The skull reached the spine with its chin, therefore being positioned almost vertically. The right arm was bent and placed slightly outwards, with the hand under the pelvis. The left arm was preserved up to the elbow. The ankles were placed almost one next to the other. Above the right elbow, on the inner side, a red fired oil-lamp was discovered (C 4661). The preserved skeleton length is $1.72 \mathrm{~m}$ ”. The discovery of the oil-lamp must certainly be considered, but we will come back to it later.

In the field diary, it is also stated that this grave, actually the skeleton, was technically documented in sketch number 712, as well as on films 224 (photo numbers 7, 8 and 9) and 225 (photos 11 and 12).
Since our analysis is based on the anthropological find, the artificially deformed skull from grave number 1542 of the Pećine necropolis, it had to be presented in detail. The method of examination needed to be much more detailed compared to skulls without artificial deformities, in order to ascertain that it belonged to the period of the Great Migration. Consequently, its anthropological measurements had to be more numerous and more detailed. We could not only use the primary cranial measurements, but also more specific ones had to be obtained, those that were the best indicators for an artificial deformity. However, these had to include only standardised anthropometric values. An analysis such as this also required a life-size X-ray.

For determining gender and individual age, there was no need to abandon the usual anthropological criteria. Recommendations have been used, which in Europe (as well as in the USA) have been applied ever since 1980 (Ferembach, Schwidetzky and Stloukal 1980). These are the criteria which, regardless of their later publication, remain a standard and only differ in modalities.

Nevertheless, the morphometry of artificially deformed skulls reaches beyond the choice of primary measurements. Primary, together with specific, skull measurements were used (a total of 39). Since, on the skull considered, neither the facial bones nor the jaws were preserved (see images), the choice of anthropological measurements had to be based only on the cerebral part. The reduced number includes the following measurements (based on marks and numeration by Knussman, 1988, s. 161-189):

For all the performed measurements, the instruments used were GPM Anthropological Instruments for Somatology and Osteology by Siber Hegner Maschinen AG from Zurich (performed in the Department of Archaeology at the Philosophical Faculty in Belgrade). Photographs and X-ray snapshots were made at the J. Gutenberg Anthropological Institute at the University in Mainz. 


\begin{tabular}{|c|c|c|c|}
\hline TYPE OF MEASUREMENT & $\begin{array}{l}\text { MEASURE } \\
\text { INDEX }\end{array}$ & NUMERATION & $\begin{array}{l}\text { VALUE FOR } \\
\text { SKULL } 1542\end{array}$ \\
\hline \multicolumn{4}{|l|}{ Length measurements } \\
\hline Maximum cranial length & $\mathrm{G}-\mathrm{OP}$ & 1 & $167 \mathrm{~mm}$ \\
\hline nasio-opisthocranion & $\mathrm{N}-\mathrm{OP}$ & $1 d$ & - \\
\hline nasion-inion & $\mathrm{N}-\mathrm{I}$ & $2 \mathrm{a}$ & - \\
\hline glabella-lambda & $\mathrm{G}-\mathrm{L}$ & 3 & 162 \\
\hline cranial base length & $\mathrm{N}-\mathrm{BA}$ & 5 & - \\
\hline foramen magnum length & $\mathrm{BA}-\mathrm{O}$ & 7 & - \\
\hline \multicolumn{4}{|l|}{ Width measurements } \\
\hline maximum cranial width & $\mathrm{EU}-\mathrm{EU}$ & 8 & 151 \\
\hline minimum frontal width & $\mathrm{FT}-\mathrm{FT}$ & 9 & 102 \\
\hline maximum frontal width & $\mathrm{CO}-\mathrm{CO}$ & 10 & 118 \\
\hline biauricular width & $\mathrm{AU}-\mathrm{AU}$ & 11 & - \\
\hline maximum biasterionic width & AST - AST & 12 & 107 \\
\hline bimastoid width & $\mathrm{MS}-\mathrm{MS}$ & 13 & 102 \\
\hline foramen magnum width & & 16 & - \\
\hline \multicolumn{4}{|l|}{ Height measurements } \\
\hline basion-bregma & $\mathrm{BA}-\mathrm{B}$ & 17 & - \\
\hline porion-bregma & $\mathrm{PO}-\mathrm{B}$ & 20 & 132 \\
\hline \multicolumn{4}{|l|}{ Perimeters and vaults } \\
\hline horizontal perimeter & $\mathrm{G}-\mathrm{OP}-\mathrm{G}$ & 23 & - \\
\hline transversal vault & $\mathrm{PO}-\mathrm{B}-\mathrm{PO}$ & 24 & - \\
\hline mediosagittal vault & $\mathrm{N}-\mathrm{O}$ & 25 & - \\
\hline mediosagittal frontal vault & $\mathrm{N}-\mathrm{B}$ & 26 & - \\
\hline mediosagittal parietal vault & $\mathrm{N}-\mathrm{L}$ & 27 & 150 \\
\hline mediosagittal occipital vault & $\mathrm{L}-\mathrm{O}$ & 28 & 132 \\
\hline \multicolumn{4}{|l|}{ Distances } \\
\hline mediosagittal frontal & $\mathrm{N}-\mathrm{B}$ & 29 & 105 \\
\hline mediosagittal parietal & $\mathrm{B}-\mathrm{L}$ & 30 & 108 \\
\hline mediosagittal occipital & $\mathrm{L}-\mathrm{O}$ & 31 & - \\
\hline
\end{tabular}




\section{RESULTS}

According to the criteria defined by D. Ferembach, I. Schwidetzky and M. Stloukal (1980), the gender of the individual to which skull number 1542 from the Pećine necropolis belonged was easily established as male. Regardless of the incomplete state of preservation and the lack of the post-cranial part, the preserved constitutional and morphological elements indicated male gender exclusively (see illustrations on T. I).

When it comes to individual biological age, the state of preservation of the cerebral skull part presented some problems. Basically, out of all of the criteria only an adequate scheme for determining age according to obliteration of the skull joints could be applied, published separately by several authors (Acsadi i Nemeskeri 1970; Olivier i Demoulin 1976). Since this scheme is not completely reliable, especially when no other scheme is being used, we consider that the age of the male individual buried in grave number 1542 from the Pećine necropolis should be determined within a time span, most likely between 30 and 40 years of age.

The measurements of the cerebral part of the skull most usually considered with artificially deformed skulls have already been shown. In order to avoid repetition, the values for skull number 1542 have been shown next to the typical anthropological marks. This refers only to the preserved skulls, those where the measuring points were available. Accordingly, of the 24 chosen measurements, only twelve skull parameters were obtained, due to the level of preservation.

Skull number 1542 from the necropolis at Viminacium - Pećine is presented using standardised anthropological projections on T. I, while its lateral radiographic image is presented on T. II.

Apart from the usual photographic images, an $\mathrm{X}$-ray snapshot (life-size) was necessary due to the specific profile of the skull. It indicates that its cerebral part does not show the usual and intact morpho-structure. The anthropological documen- tation doubtlessly indicates that it was an artificial deformation made using bandaging during the lifetime of the deceased. In other words, traces of artificial deforming are apparent. This deformity shows on all of the big bones of the cerebral part. Due to artificial deformation, the shapes of the frontal and occipital bones were altered, along with those of the parietal bones. Based to their configuration, we can define the bandaging zones, of which there were certainly two. One of them was frontal-occipital, while the other was parietal-occipital. The effects of such bandaging on this skull are still very striking, although it is known that, in cases of artificial deforming during lifetime, each skull tends to return its natural shape (Mikić 2007/a). Generally speaking, this is why artificial deformations are much more striking at a younger, rather than at an older age.

\section{DISCUSSION AND CONCLUSION}

The sondage CLIX was opened on the $18^{\text {th }}$ of June 1980, as shown on page 741 of the field diary for the site of Viminacium - Pećine. Further on, it is indicated that it was a so-called block-sondage, measuring $10 \times 5 \mathrm{~m}$. As a result of its size, it was sub-divided into blocks, sectors and extensions.

Due to its specific content, the excavation of this sondage lasted for several years. For example, grave number 1542 is mentioned in the field diary on pages 1533 and 1534 , written on the $17^{\text {th }}$ of May 1982.

Now we will return to the find of the oil-lamp, discovered close to the right elbow of skeleton number 1542. Since this grave was excavated within the group of graves with numbers 1507 and 1514, both without grave-goods, the oil-lamp should first be regarded outside the archaeological context. This would indicate that it was discovered in a secondary position, since sondage 159 was densely filled with graves and skeletons, even in its extensions, and was excavated for several years. 
Another consideration refers to the possible pathology of the cerebral part of skull number 1542 , requiring a completely different interpretation. After comparisons with other skulls from the Više Grobalja necropolis and comparing it with data from a variety of papers (eg. Buikstra i Ubelaker 1994; Freiss i Baylac 2003), it can be ascertained that this skull was artificially deformed, therefore ascribing it to the populations younger that the Roman one, which inhabited Viminacium after the $5^{\text {th }}$ century.

The third conclusion, actually our general conclusion, regards the discovery of the group of skeletons (graves 1507, 1514 and 1542), archaeologically identified as having a definite co-relation.

As already known, the names for the Viminaciumu cemeteries were taken according to the cadastre of the CU Požarevac. The Pećine and Više Grobalja cemeteries belong to the so-called southern Viminacium cemeteries, and are positioned one next to the other. The Više Grobalja cemetery is located to the south-east of the Pećine necropolis. The graves discussed were discovered in the eastern appendix of sondage 159 at Pećine. - It transpires that these graves should then belong to the north-western part of the necropolis from the period of the Great Migration (Više Grobalja II). This conclusion is based on the discovery of skull 1542 with its specific morphology.

Finally, our research does not affect the archaeological interpretation of the cemeteries from the Great Migration period in Viminacium (Ivanišević et al., op. cit.), since in those graves there were no grave-goods. The only exception is the area of the cemetery itself, which was slightly enlarged. On the other hand, when considered anthropologically, the younger cemetery from the period of the Great Migration, Viminacium - Više Grobalja, possessed one more artificially deformed skull (along with five others, previously discovered and published), with at least two more adult skeletons.

\section{BIBLIOGRAPHY}

Acsady, Gy. and Nemeskeri, J. 1970

History of Human Life Span and Mortality, Akademiai Kiadó, Budapest.

\section{Buikstra, J. E. and Ubelaker, D. H. 1994}

Standards for Data collection from human skeletal remains, Arkansas Archaeological Survey Research Series, No 44, Fayettville, Arkansas: Arkansas Archaeological Survey.

\section{Ferembach, D., Schwidetzky, I. and Stloukal,} M. 1980

Recommendations for Age and Sex Diagnoses of Skeletons, Jour. Human. Evol. 9: 517-549.

Friess, M. and Baylac, M. 2003

Exploring Analysis of Pracrustes Aligned Outlines, Amer. Jour. of Physical Anthropology 122: 11-22.

Ivanišević, V., Kazanski, M. et Mastykova, A. 2006

Les necropoles de Viminacium a l'epoque des grandes migrations, Paris: Centre de Recherehe d'Historie et Civilisation de Byzance.

\section{Knussmann, R. 1988}

Anthropologie. Handbuch der vergleichenden des Menschen. Wesen und Methoden der Anthropologie, Stuttgart, New York.

\section{Mikić, Ž. 2007}

Nekropole seobe naroda na Viminacijumu - antropološka revizija, Arhaika 1: 209-217.

\section{Mikić, Ž. 2008}

Deux necropoles de la grande migration des peuples a Viminacium, Balcanica XXXVIII: 45-50.

\section{Mikić, Ž. (in print)}

Lobanjski tragovi usled nošenja tereta trakom preko glave - slučaj Viminacijum /Njive kod Mlave, 
Zbornik Filozofskog fakulteta posvećen A. Jovanoviću, Beograd.

Olivier, G. and Demoulin, F. 1976

Practique Anthropologie a l' usage des Etudes. Paris.

\section{RESUME}

\section{VIMINACIJUM - NEKROPOLE I LOKACIJE SAHRANJIVANJA TOKOM VELIKE SEOBE NARODA}

KLJUČNE REČI: SEOBANARODA, STANOVNIŠTO, NEKROPOLE VIMINACIJUMA, LOKACIJE SAHRANJIVANJA, ANTROPOLOŠKI SADRŽAJ NEKROPOLA.

Od ranije je poznato da su nekropole Burdelj, Više grobalja I i II i Lanci, zapravo četiri lokacije na kojima se vršilo sahranjivanje tokom velike seobe naroda. Te četiri lokacije su već ušle u arheološku literaturu, što ne želimo da osporavamo. Cilj ovog priloga je da se postojećim saznanjima pridodaju i podaci dobijeni antropološkim kriterijumima.

Na lokaciji Njive kod Mlave ranije je u tzv. top-sondi otkrivena jedna specifična ženska lobanja koja je kao grobni prilog imala jednu tipičnu germansku fibulu. Lobanju tog skeleta karakterišu tragovi usled nošenja tereta trakom preko glave tokom dužeg perioda života, ali što je kao pojava i ranije bilo konstatovano na ovim prostorima. Nedavno je publikovana kao treći ovakav nalaz, svakako iz perioda velike seobe naroda. Međutim, u ovom slučaju ostaje otvoreno pitanje, da li se radi o usamljenom nalazu ili pak nekropoli, koja je mogla biti identifikovana samo pomenutom sondom na lokaciji Njive kod Mlave, ali gde detaljnija arheološka istraživanja nisu mogla biti nastavljena.

Ovaj prilog je baziran na nalazu jedne veštački deformisane lobanje na lokaciji Pećine, u sondi broj 159 (čijim iskopavanjima je rukovodio M. Korać). Posle svih potrebnih upoređivanja, kako sa tridesetak artificijalno deformisanih lobanja sa lokacija Više grobalja, što predstavlja izuzetno velik broj i u najširim okvirima, tako i sa odgovarajućom literaturom, sigurni smo da se ona hronološki mora vezati za veliku seobu (videti T. I i T. II). Nalaz keramičkog žiška u blizini skeleta broj 1542, koji je u okruženju nekoliko grobova bez priloga $(1507,1514)$ u inače najkomplikovanijoj sondi na Viminacijumu, imamo razloga da smatramo da je zatečen u sekundarnom položaju. Prioritet smo dali morfologiji prikazane lobanje, što se svakako ne može osporavati.

S obzirom da je nekropola Više grobalja locirana jugoistočno u odnosu na nekropolu Pećine, posmatrana grupa grobova pronađena u istočnom proširenju sonde 159 (na Pećinama), pokazuje da se oni nadovezuju na severozapadni deo mlađe nekropole (na lokaciji Više grobalja). Ali, kako se lokacije Pećine i Više grobalja katastarski graniče, a obe pripadaju tzv. južnim nekropolama Viminacijuma, naš zaključak bi glasio: Naše istraživanje nije osporilo arheološku interpretaciju o nekropolama seobe naroda, nego je samo proširilo antropološki sadržaj mlađe nekropole Više grobalja, i to za jednu artificijalno deformisanu lobanju i dva skeleta odraslih individua. 

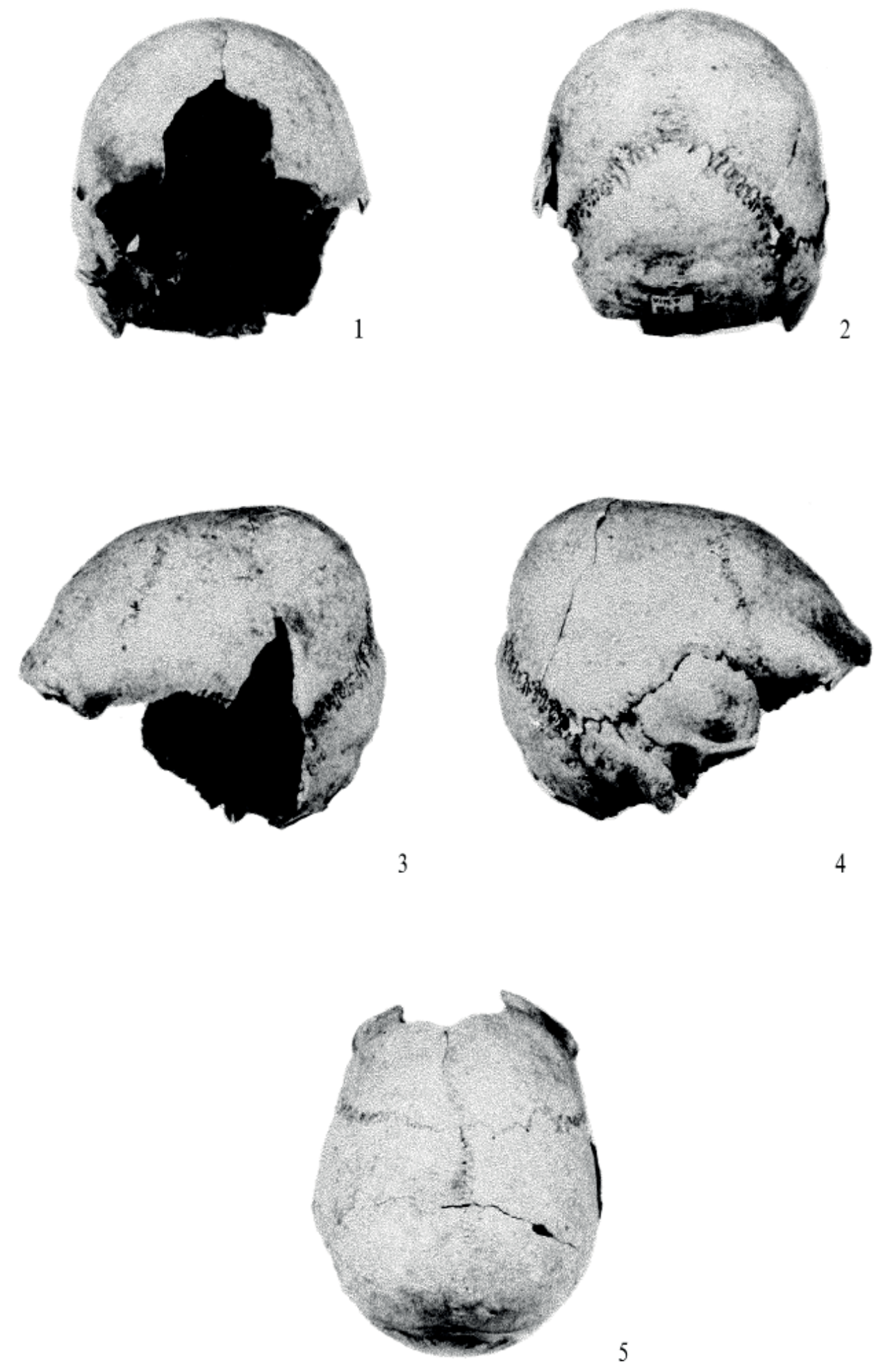

T. I

Viminacium / Pećine No 1542

1 - Norma frontalis; 2 - Norma occipitalis; 3 - Norma lateralis sinister;

4 - Norma lateralis dexter; 5 - Norma verticalis 


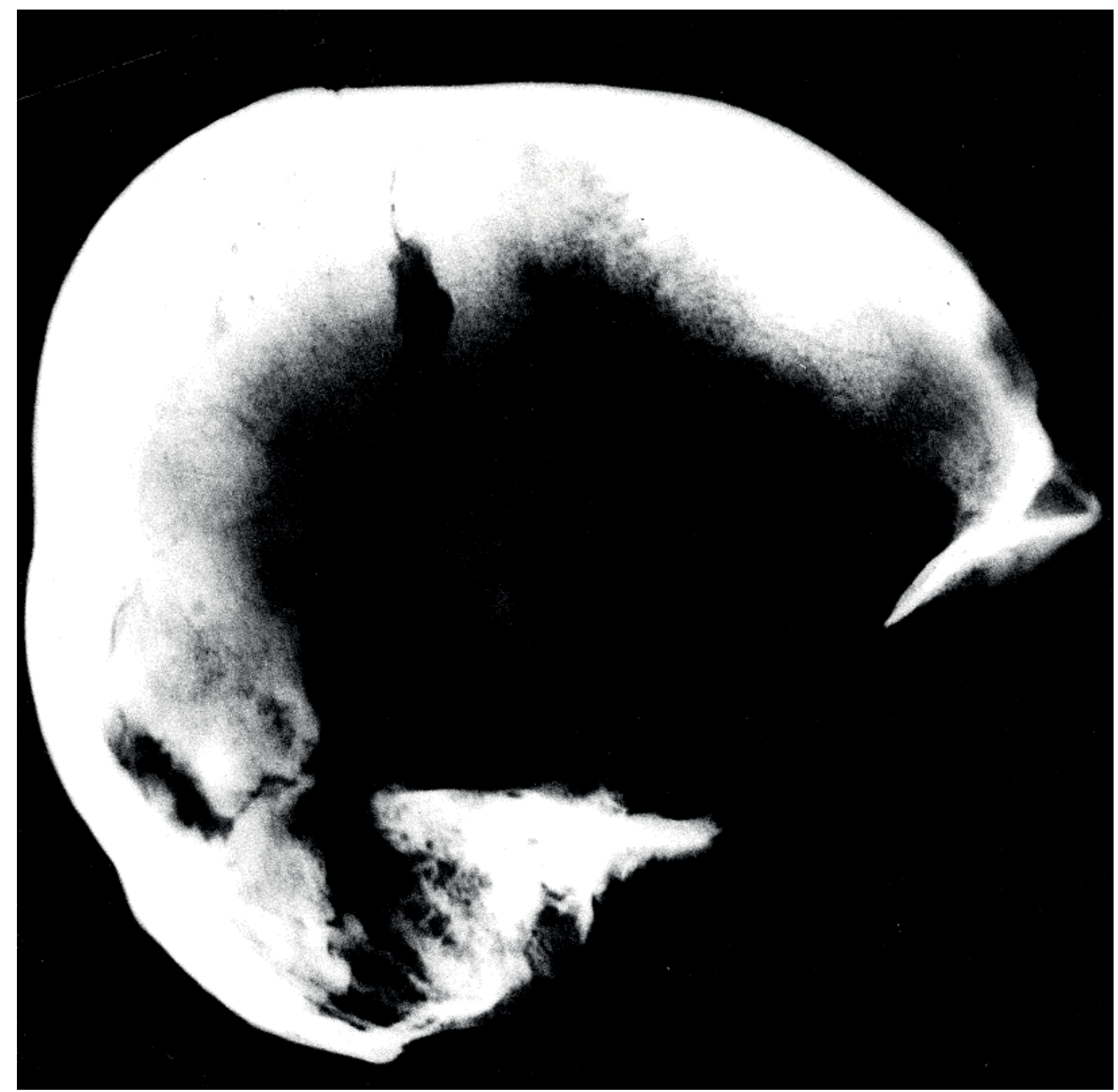

T. II

Viminacium / Pećine No 1542

Rö - Norma lateralis dexter 